\title{
TIME AS A RESOURCE OF THE INFORMATION ECONOMY
}

\author{
Dmitry Yadransky', Elena Chumak ${ }^{2}$ \\ Ural State University of Economics, Russian Federation
}

\begin{abstract}
The article considers the category "time" in terms of the information economy. The subject of the study is the category of time acting as a resource of the modern economy. The main purpose of the article is the formation of the author's concept of time as an economic resource in the conditions of the information economy. The methodological base is made up of concepts of foreign and domestic researchers regarding the concept of time; first of all, the concept of M. Heidegger. In combination with a set of such general scientific and special methods of cognition as a dialectical, historical, systematic, descriptive, selective one, the article reveals the significance of time as an economic resource. Existing methodological approaches to the study of this category become critically comprehensible. The concept is based on a resource approach. As a result, the crisis of applying the classical methodology of the industrial economy to the study of time as a resource of the information economy is determined. The main problem is the fact that the value of an information product is largely dependent on subjective factors and cannot be related to the total time spent on producing such a product. The transformation of the influence of time on the processes of production and consumption in terms of the information economy is considered. Conclusions. Based on the results of the study conducted, time as a public resource is proposed to be considered in 3 aspects: as a production resource (time of work), in which it reveals internal competition with other types of resources; as a promotion resource, in which the time of consumption of the corresponding product has an alternative with the time of consumption of another similar product (commodity competition); time as a resource of consumption or a personal resource (which determines the possibility and desire of the individual to consume a particular good). The article defines mechanisms of the influence of the time factor (as one of the important economic resources) on the process of social reproduction. The author's concept of information flow rate is formulated, the resource phase of time is characterized, and the author's list of differences of time functions in the information and classical economy is proposed. The author's category "speed of information use" has been introduced, which is the basis for considering the possibilities of consumers of information to an adequate choice of the object of consumption. Differences of time in the classical and information economy are formulated and their comparative analysis is carried out. Specific features of consumption in the information economy, where consumption is associated with the search and interpretation of necessary information, are determined. The factor that complicates consumption is called the increasing rate of the information flow, expressed by the increase in the number of messages, which complicates the search and increases the number of errors in the choice of the information product. As a factor determining the price of labour in the information economy, it is suggested to consider the social demand for a particular product (information) and the subjective evaluation of the product by the consumer. It is proposed to consider time as a complex economic factor that acquires its resource value, only coinciding at a certain point of time with such characteristics of information as: content (adequacy), completeness, and price. In fact, at the theoretical level, an economic model of the space-time continuum is proposed, which creates the prerequisites for continuing the study of the proposed theory.
\end{abstract}

Key words: time, factor, information flow rate, creator of information product, price, resource.

JEL Classification: A14, B49, J20

\footnotetext{
Corresponding author:

${ }^{1}$ Ural State University of Economics, Russian Federation

E-mail: jadransky@yandex.ua

${ }^{2}$ Ural State University of Economics, Russian Federation

E-mail: lena22021977@yandex.ru
} 


\section{The relevance of the research topic}

In today's dynamic world, time is one of the most important economic and scientific categories. Given its decisive significance for economic processes, not all economic theories consider time as an economic category. Of course, this has an objective explanation due to the fact that there is no single universally recognized theory explaining and describing such a thing as "time", even at the present time, even in philosophy. Economics, being a quantitative science, cannot exist without a clear methodological basis and adequate quantitative indicators. The existing theories of time, in fact, are a part of general theories and philosophical teachings, which are descriptive and not suitable for the use in the applied economics. The novelty of the topic is that under the conditions of the information economy, the "time" category from the viewpoint of the resource approach was not previously considered.

In the description of economic processes, modern researchers use two basic paradigms of approaches to the study of time: Kantian and Marxist. It should be noted that both were formed in somewhat different epochs (respectively, preindustrial and industrial), while the modern stage of development of society and economy is attributed by more and more authors to the post-industrial era. We do not insist that the existing approaches have completely lost relevance, but in our view, at least, there is a need for their systematic scientific understanding within the framework of modern economic knowledge.

Attempts by most economists to avoid studies of time itself as a resource, we associate with I. Kant's narratives, in particular: "Time is not an empirical concept derived from experience ... Time is a pure form of sensory contemplation (Kant, 1998)....Time is neither more nor less than a form of inner feeling, that is, contemplation of us and our inner state ... Time is an a priori formal condition of all phenomena in general..." (Kant, 1998). Obviously, when carrying out calculations, the use of existentiel categories is difficult. Moreover, under the conditions of the information economy, the process of production and consumption often acquires a virtual character and is differentiated by subjective time (the speed of information labour depends on the speed of the worker's mental processes, the rate of consumption from the personal time available to the consumer). It should be noted that Marxism and the dialectical materialism that developed in the USSR (as basic philosophical movements) gave a significant impetus to the use of time in certain instrumental studies. According to the representatives of dialectical materialism, time is an order, a sequence of changes in the stages of material processes, respectively - space and time are inseparable from matter (Konstantinov, 1963). However, in modern information labour processes, dialectics loses its semantic basis - the opposition (since the act of production and consumption can not necessarily be divided).

Proceeding from the fact that time in dialectical materialism is an objectively real form of the existence of a movement that characterizes the sequence of the unfolding of material processes and their duration, the rationing of labour has become a logical economic embodiment of this concept. The loss of clear boundaries of the movement of material processes within the modern reproduction process, as well as the high degree of its virtuality, in fact, lead to the boundaries of modern understanding of matter (5D movies, vegetables with meat taste, etc.). We do not enter into a discussion on changing the understanding of matter, but we consider it necessary to note that the information process of social reproduction is a continuous process (Fig. 1), which cannot be correctly broken down in stages. Moreover, in this process, there may not be at all a material basis (artefact).

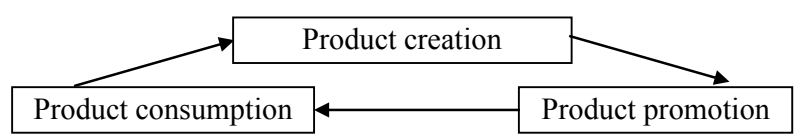

Fig. 1. The process of social reproduction

in the information economy

Undoubtedly, the process of reproduction takes place during a certain time, but due to the fact that phases are shown in Fig. 1 do not carry of a pronounced nature in the information product, their differentiation by time is difficult. Also, it should be noted that the value of the product will largely depend on subjective factors and cannot be related to the total time spent on producing such a product. Thus, the methodological basis for studying time in modern economic processes requires the use of a more specific methodology. In this case, dialectical materialism and classical Marxism do not fully take into account peculiarities of social reproduction of the modern information product. In our opinion, the most universal methodological basis of theorizing is phenomenology (in the general principles described by Martin Heidegger (Heidegger, 1993)). However, M. Heidegger's methodology as a phenomenological concept has a sufficiently high level of theorizing, which also makes it unsuitable for solving applied economic problems.

Statement of the research problem. The above processes form a special urgency for conducting such a study with the purpose to clarify the role of time in modern economic processes. Achieving the purpose requires the simultaneous fulfilment of a number of tasks, in particular: the study of the transformation of scientific concepts about the category "time" in the modern economy; the possibility of applying the resource approach to the "time" category; the formation of directions for a possible quantitative measurement of time as an economic resource. 


\section{The category of "time" in the modern economy}

The first profound studies of the influence of time on the results of social production were conducted by K. Marx (Marx, 1968). To date, it is his work that has the greatest practical importance. According to Karl Marx: "Any material wealth is only a fleeting embodiment of this social labour, the crystallization of the production process, the measure of which is time - the measure of the movement itself" (Marx, 1978). K. Marx proposed the Law of Economy of Time (Marx, 1968). This law as a whole is fair for the conditions of the industrial economy. However, as virtualization of socio-economic relations progresses, the theses of this law lose their adequacy. In modern scientific literature, studies related to the analysis of time often came down to:

- consideration of the time factor in justifying management decisions (these studies can be viewed in the context of time accounting in the process of intellectual work);

- analysis of the actual time spent on material production (technical standardizing as a form of accounting for physical labour).

Foreign and domestic scientists made a significant contribution to the first direction: H. Bierman (2003), I. Blank (Blank, 2003), P. Vilenskii (Vilenskii, 2008), and others. To the second - F. Taylor (Taylor, 1991), A. Gastev (Gastev, 1972), and a significant number of modern researchers. A separate line of research was also the features of modelling of economic processes under conditions of dynamic temporary changes (Zang, 1999). The concept of an economy based on a time factor was introduced by the German economist S. Gesell as an alternative payment system (Gesell, 1916). K. Marx (Marx, 1978) considered time as the most important economic category and as the main factor in the growth of labour productivity (time-saving). However, the globalization of the economy and the change of forms of competition among producers of the information product make classical concepts of time less suitable, which in fact are the product of another economic paradigm (the commodity economy). At the same time, according to K. Marx, time to some extent determined the relationship between the producer and the consumer (reduction in the time costs led to a reduction in the product price and, consequently, to an increase in customer satisfaction). At the present stage, time turns into one of the most complex resources of the information economy, which cannot be characterized by simple dependencies. Thus, we propose to consider time in the information economy as a complex, multidimensional category that determines the nature of relations between the producer and the consumer of the information product.

\section{Resource approach to the category of "time"}

Resources, according to the author of the economic dictionary V. Zolotogorov, are "...wealth and their sources" (Zolotogorov, 2004). Time, in this context, can act as a source of wealth only within the framework of the industrial economy. Saving of time determines the reduction of circulation costs, the growth of labour productivity, and so on. However, in the context of the information economy, the speed of circulation is largely determined by the consumer, and not by the producer (seller). In consequence of this, the role of time as a resource of the information economy is substantially transformed (but not diminished).

In the framework of this study, we will try to offer the author's concept of time as a resource in the information economy. In the basis of theorizing, we lay the resource approach. The fairness of this approach, in our opinion, allows adequately correlating the aspect of production and consumption of an information product with the only, unconditionally exhaustible resource of a person the time of life (Yadransky, 2013).

Time as a public resource can be considered in 3 aspects (in accordance with Figure 1):

- as a production resource (working time), in which it reveals internal competition with other types of resources (including past labour);

- as a promotion resource, in which the time of consumption of the corresponding product has an alternative with the time of consumption of another similar product, with the same amount of benefits obtained from consumption (commodity competition); - time as a resource for consumption or a personal resource (which determines the possibility and desire of the individual to consume a particular good).

It should be noted that the first two resources can be replaced by alternative ones and only the latter is essentially non-alternative.

The process of creating an information (and not only) product is also value-differentiated by the time of life (the individual value of the time of the subject creating the product). It is this that determines the basic cost of an information product, which often has no material costs at its core. In this case, the price, along with the public value, is determined by the individual value of the time of its developer (creator) and the consumer. It should be noted that often without having a material nature at its core, information can easily be reproduced. In this case, the developer's time is almost the only lost resource.

In this context, the time is of the principal importance of the individual, regardless of the latter's involvement in social reproduction or consumption. The individual's lifetime is spent regardless of his desire and forms of social activity, therefore, each individual has a limited time to realize the available intellectual and physical potencies (which in turn were acquired as a result of 
the direct costs of the individual lifetime). This allows us to consider K. Marx's thesis in a new way: "for the individual, as well as for society, the comprehensive nature of its development depends on the preservation of time. Any savings, in the end, comes down to saving time" (Marx, 1968). Speech in the case under consideration can go about saving own time as the unique exhaustible individual resource. At the same time, the time to prepare for the creation (consumption) of an information product and the immediate time for its creation (consumption) are simultaneously an object of saving.

By analogy with the creators (consumers) of the information product, the entrepreneur is also interested in saving time since minimizing the time to prepare and create an information product increases economic results. However, over the fact that the phases of creation and consumption of an information product cannot be clearly structured, the increase in the productivity of information labour equally depends on its creator and consumer and, consequently, the time savings (in the Marxist sense) goes beyond the capabilities of a particular producer. It should be noted that the information economy reduces risks of the entrepreneur. Not having a material basis, and accordingly, the initial costs of material resources, entrepreneurial losses in case of impossibility of realization of the given goods are minimal. Given the fact that classical political economy classifies wages as added value, the nature of entrepreneurial risk varies significantly.

Since the process of production, promotion, and consumption of the information product has a number of features, there is a need for a deeper analysis of the internal structure of the reproduction process in the information society. Consumption is associated with the search for the necessary information and its interpretation. More and more increasing rate of the information flow, which is expressed in the growth of the number of messages, fundamentally complicates this search and increases the number of errors in the choice of the information product. Speaking about the price of labour in the information economy, we can state that the main parameter determining the price is public demand and subjective evaluation of the product by the consumer. However, the product may be completely unnoticed and, therefore, completely unvalued.

An interesting point of view on time as a resource is proposed by the Russian author A. Baskin who made an attempt to comprehend the category of "time" in the postindustrial society (Baskin, 2006). The author introduces the concept of static and dromological resources, assuming the bivalence of time as an economic resource (characterized by interval duration and irreversibility of the move) (Baskin, 2006). However, it is due to the irreversibility of the course that time is a resource in the information society. In fact, information becomes a resource only at a certain point in time, provided that it was noted by the consumer in the general information flow. Irreversibility of the move makes the information resource permanently obsolete, and, consequently, losing its resource value (depreciates). It should also be noted that, in addition to timeliness (which discloses the phase of time as a resource), there are other characteristics that determine the value of information as a commodity. To these characteristics we include the price, adequacy, completeness. Each of these parameters can be quantified, but in the information economy, information acquires the status of a resource only when the specified parameters coincide. Thus, talking about the information economy is more correct not from the standpoint of time capacity (as suggested by A. Baskin), but from the position of time-dependence. In other words, only depending on the time factor (timeliness), information acquires economic value and becomes an economic resource. Accordingly, the laws of the classical economy begin to function. In general, the resource character of time is manifested in the one-moment coincidence of parameters shown in Fig. 2.

\begin{tabular}{|l|c|c|c|}
\hline Production & \multirow{2}{*}{ Price } & Content & Completeness \\
\cline { 1 - 3 } Consumption & Timely & - & - \\
\hline Content & - & Timely & - \\
\hline Completeness & - & - & Timely \\
\hline
\end{tabular}

Fig. 2. Description of the resource information phase

In our opinion, information as a commodity has a certain value only if factors shown in Fig. 2 on the part of producers and consumers coincide. So, the price (liquidity) of an information product (which quickly becomes obsolete) is determined not only by the fact of completeness and adequacy of information but also by the availability of funds from the buyer at a particular moment in time. Timeliness as a characteristic of a certain time interval is, in this case, a quantitative reflection of the time factor. It should be noted that as a consequence of the irreversible flow of time, this time interval (timeliness) is irretrievably lost (information becomes obsolete) in an extremely compressed period. In essence, this allows us to talk about the rate of the information flow (as an element of the information economy), calculated similarly to the speed in mechanics. In this case, the speed of information is a value equal to the ratio of the change in income from the information product (information) to the time interval for which this change occurred (1):

$$
\bar{v}=\frac{d \bar{X}}{d t} \text {. }
$$

It is a combination of the factors shown in Fig. 2 where is the manifestation of time as a resource of the information economy. It should be noted that in this case, the economic result is a consequence of a combination of two types of resources - information and time. Thus, 
time, being a resource of the information economy, has the property of direct influence on the economic result, so it requires clarification from the viewpoint of the possibility of its quantitative measurement.

\section{Directions of possible quantitative measurement of time as an economic resource}

To consider time as an independent indicator of the effectiveness of economic processes in the information economy is possible, taking into account a number of limitations. Thus, the cumulative expenditure of time does not correctly reveal the labour coefficient of the information product, since they do not take into account the intensity of the information flow associated with this process. In this case, it becomes necessary to introduce the category "information flow rate", which should characterize the intensity of the receipt of information messages (or units of information) per unit time.

It is possible to consider the time factor within the quality of the flow (organization) of economic processes, however, it is necessary to take into account differences of this factor in different models of the economy. The differences are given in Table 1.

The information product differs from the noninformational one in that its consumption is more structured by time. Since most of the authors of the information resource are referred to as inexhaustible, time (obsolescence) is practically its only limit. In this case, it seems expedient to introduce the category "speed of information use". In this case, this indicator will disclose the average speed of the information flow used by the consumer of information during a certain time period (year, month). Given that this indicator is dependent on a number of material resources, in particular material, energy, the main differentiating factor is time, or rather an individual (or cumulative) time resource of the consumer.

It is worth paying attention to the opinion of $\mathrm{A}$. Marshall, who in particular notes: "the factor of time, which underlies the main difficulties in solving almost any economic problem, is in itself absolutely constant: nature does not know the absolute division of time into long and short periods, they invisibly pass into each other, and what for one problem appears as a short period turns out to be long for another one" (Marshall, 1968). Adding to this thesis the opinion about the subjective perception of one's own time as an exhaustive resource, it becomes obvious that even the attitude towards the duration of a socio-economic process (and accordingly the desire to take part in it) acquires subjectivity and passes into the plane of socio-psychological analysis. American professor Paul Heyne notes that "any good is changeable. A higher money price encourages people to search for and use substitutes. And the higher the price, the greater the use of bypass routes" (Heyne, 1992). The number of similar benefits in the information economy can be many times greater than in the industrial economy. However, the high information flow rate makes it difficult to find an alternative.

In our opinion, the use of a price approach to understanding the causality of economic practices in the event of a change in the choice of an alternative in the information economy is not justified. We attribute this to the fact that price as an objective characteristic of the socially necessary expenditure of time loses its meaning. As an alternative to the price factor is the time factor. In particular, time, as a consumer resource e, cannot be replaced. Undoubtedly, in part time expenses can be compensated by the acquisition of time-saving services, and within the framework of the cumulative time resource by means of prolonging longevity. However, when it comes to the consumption of certain information, the rate of its consumption depends on the rate of the information flow and the individual ability to process (absorb) the information flow at the specified speed.

It is worth paying attention to the time that an individual considers possible to spend on the creation (use) of a certain amount of public utility. The price, in this case, reflects the time necessary for the exchange of its exhaustible resource (lifetime) to receive in return a certain amount of material and non-material goods. From these positions, the main value in assessing any economic practices, in our opinion, is the desire (willingness) to exchange its temporary resource (life) for a certain good. It is from the subjective sense of justice of such an exchange that satisfaction (dissatisfaction) with the economic exchange arises.

Table 1

Differences in time in the classical and information economy

\begin{tabular}{|l|l|l|}
\hline \multicolumn{1}{|c|}{ Index } & \multicolumn{1}{|c|}{ In the classical economy } & \multicolumn{1}{c|}{ In the information economy } \\
\hline Level of human development & Total time required to prepare & $\begin{array}{l}\text { The intensity of the information-educational flow } \\
\text { (the amount of information processed by a person) }\end{array}$ \\
\hline Costs of direct and embodied labour & Relative time expenditure (efficiency) & Relative time expenditure (value of time) \\
\hline The efficiency of economic processes & Comparative time spent on production & Comparative consumption time for consumption \\
\hline $\begin{array}{l}\text { The price, as an indicator of the cumulative } \\
\text { expenditure of time }\end{array}$ & Value as an objective measure of time & Price as a subjective value indicator \\
\hline The speed of economic processes (turnover) & Duration (total costs) & $\begin{array}{l}\text { The effectiveness of the information product } \\
\text { (the ability to cause consumer satisfaction for the } \\
\text { minimum expenditure of personal time) }\end{array}$ \\
\hline
\end{tabular}


Returning to the thought of P. Heyne, who considers time in a slightly different context, it should also be noted that the researcher believes that: “... buyers need time to find substitutes and start using them (i.e. goods). Manufacturers also take time to come up with substitutes, produce them and draw attention to them. As a result, the scale of the increase or decrease in purchases depends very much on the duration of adaptation to price changes" (Heyne, 1992). In this context, P. Heyne, in fact, continues the idea of A. Marshall: "Time is also needed for consumers to get used to substitutes that can be used instead of this product, and perhaps also for producers to become accustomed to making such substitutes in sufficient quantity. It may also take time to develop a habit of new products and to discover ways of using them economically" (Marshall, 1968).

However, these approaches are more closely related to the valuation of a tangible commodity. The information product is much more complicated in terms of its replacement. On the one hand, in the dynamic information flow, it is necessary to find an analogue, on another one - the consumer often cannot, until the end of consumption, present the degree of satisfaction with the consumption of this product. Being unsatisfied, the consumer has probably already exhausted the resource of time (in consequence of which the corresponding product has lost value) or he or she needs another (not similar) product because the time period has changed. Consequently, in this case, the basis of consumer activity in the information economy is the process of promoting the information product. This process is reduced to the practical implementation of the time factor as an economic resource.

All the above gives grounds for using time as a category of economic practice in the conditions of the information economy and allows considering it as an important economic resource in scientific theorizing. This resource explains and characterizes the sphere of relations, which until today have not been fully explored.

Modern attempts at two-dimensional measurement of supply and demand of an information product require their translation into a three-dimensional analysis plane, in which the third dimension is time. It is this 3-dimensionality, in our opinion, that determines the entire system of economic relations in the information economy. We associate this with the fact that any exchange occurs not only in space, but also in time, and accordingly, the complication of the nature of exchange forces us to rethink the time factor in modern economic models. On the other hand, time determines the appropriateness of economic relations and the degree of their antagonism.

Thus, we can state that time as a resource of the information economy is fundamentally measurable and can be quantitatively described. However, within the framework of this research, it is not possible to go completely to a quantitative description of time because of the need to continue theoretical studies, primarily aimed at determining the influence of the time factor on changing demand and supply of an information product.

\section{References:}

Baskin, Artem Ilich (2006). Vremya v sisteme ehkonomicheskih resursov postindustrialnogo obshchestva [Time in the system of economic resources of the post-industrial society] (PhD Thesis) Sankt-Peterburg: S.-Peterb. un-t ehkonomiki i finansov. (in Russian)

Bierman, H., Smidt, S. (2003). Kapitalovlozheniya: EHkonomicheskij analiz investicionnyh proektov [Capital investments: Economic analysis of investment projects]. - Moscow: YUniti (in Russian).

Blank, I. A. (2001). Investicionnyj menedzhment: Uchebnyj kurs [Investment Management]. - Kiev: EHlga NikaCentr (in Ukrainian)

Vilenskii, P. L., Livshic, V. N., Smolyak, S. A. (2008). Ocenka ehffektivnosti investicionnyh proektov [Evaluation of the effectiveness of investment projects: Theory and practice]. Moscow: Delo (in Russian).

Gesell Silvio (1916). Estestvennyj ehkonomicheskij poryadok [The natural economic order]. Retrieved from: http://www.demandandsupplY.ru/gesellpartioutline.html (accessed 25.01.2018)

Gastev, A. K. (1972). Kak nado rabotat [How to work] Moscow: EHkonomika (in Russian).

Zang, V.-B. (1999). Sinergeticheskaya ehkonomika. Vremya i peremeny v nelinejnoj ehkonomicheskoj teorii [Synergetic economy. Time and changes in nonlinear economic theory]. Moscow: Mir (in Russian)

Zolotogorov, V. G. (2004). EHkonomika: EHnciklopedicheskij slovar [Economy: Encyclopaedic Dictionary] Minsk : Knizhnyj dom (in Belarus)

Kant, Immanuel (1998). Kritika chistogo razuma : S variantami per. na rus. i evrop. yaz. [Criticism of pure reason] Moscow: Nauka (in Russian).

Konstantinov, F. V. (1963). Dialekticheskij materializm [Dialectical materialism] / Moscow: Politizdat (in Russian) Marx, K. (1978). Teorii pribavochnoj stoimosti [Theories of surplus value / The fourth volume of "Capital"]. Moscow: Izdatelstvo politicheskoj literatury (in Russian)

Marx, K., Engels, F. (1968). Sochineniya [Compositions]. Moscow: Izdatelstvo politicheskoj literatury (in Russian) Marshall Alfred. (1983). Principy politicheskoj ehkonomii [Principles of political economy / Economic thought of the West]. Moscow : Progress (in Russian)

Taylor, F. W. (1991). Principy nauchnogo menedzhmenta [Principles of Scientific Management]. - Moscow: Kontrolling. (in Russian) 
Heidegger, M. (1993). Vremya i bytie: Stati i vystupleniya [Time and Being: Articles and speeches]: Moscow: Respublika. (in Russian)

Heyne, P. (1992). EHkonomicheskij obraz myshleniya [Economic way of thinking] Moscow : Delo : Gatallaxy. (in Russian).

Yadransky, D. M. (2013). Chas, jak bezaljternatyvnyj obmezhenyj resurs [Time as a non-alternative is a limited resource]. Naukovi praci Kirovoghradsjkogho nacionaljnogho tekhnichnogho universytetu. Ekonomichni nauky, № 23, p. 199-206. 